\title{
Distinct Role of Estrogen and Er (A and B) in Various Brain Disease Anomalies
}

\author{
Seema Bansal and Kanwaljit Chopra* \\ Punjab University, India
}

Submission: April 27, 2017; Published: June 02, 2017

*Corresponding author: Kanwaljit Chopra, Professor, Dean, Faculty of Pharmaceutical Sciences, University Institute of Pharmaceutical Sciences, Panjab University, Chandigarh-160014, India, Tel: +91-9812904586; Email: dr_chopra_k@yahoo.com

\section{Background}

Estrogens, the primary ovarian hormones and are accountable for the proliferation of cells and tissues linked to reproduction [1]. Along with the functions on female reproductive system, estrogens also play a pivotal role in the maintenance of physiological and pathological states including central nervous system physiology $[2,3]$. Due to this wide regulatory control, it is accepted that estrogens have chief functions not only in female but also in male physiology [4]. Although the physiological importance of estrogen and its mechanisms of actions has significantly enlightened, however, we are only beginning to decipher the roles of estrogen receptors ( $\alpha$ and $\beta$ ) in different organs and to elucidate how subtype selective ligands acting through these receptors, can prevent or treat various diseases. Thus distinctive role of ER- $\alpha$ and $\beta$ in various brain disease anomalies has been reviewed here in.

\section{Alzheimer's Disease (AD)}

Estrogen deficiency has been considered as a major risk factor in $\mathrm{AD}$ as widespread epidemiological studies suggests that hormone replacement therapy can defend against the start and progression of the AD. Estrogen can encourage the development of nerve processes [5] and make improvements in synaptic plasticity [6]. ERs are expressed in forebrain cholinergic neurons, which are familiarly involved in learning and memory $[7,8]$ and estrogen treatment enhances cholinergic functions in ovariectomized animals [9]. Other putative advantageous actions include escalation of cerebral blood flow [10], enhancement of glucose transport into the brain and reductions of $\beta$-amyloid development [11].

Some reports in the literature indicate that both ER $\alpha$ and ER $\beta$ agonists show protective effect against AD. PPT (selective ER- $\alpha$ ligand) and DPN (selective ER- $\beta$ agonist) showed protective effect against amyloid-induced toxicity in cultured neurons $[12,13]$. Similar results were also observed when both PPT and DPN showed similar types of results when were administered in female 3xTg-AD mouse model. However, other studies suggest

thatER- $\alpha$, but not ER- $\beta$, levels associated with $\mathrm{AD}[14,15]$. Another study reports administration of PPT enhanced the capacity of estradiol against deposition of amyloid- $\beta$ in brain regions (amygdale and hippocampus), however, DPN treatment did not show any effect on amyloid- $\beta$ accumulation [16]. Selective ER- $\beta$ agonist (genistein) improves learning and memory in AD rats via its antioxidant effect [17]. These findings clearly postulate that subtype selective estrogen receptors play a significant role in modulators against $\mathrm{AD}$

\section{Parkinson's Disease (PD)}

Epidemiologic and clinical evidences suggest that female sex hormone may influence the onset and severity of PD symptoms. Increased prevalence rate of PD in men compared to premenopausal women (3:2 ratio) suggests that gonadal hormones mainly estrogen, plays protective role in PD pathologies [18]. Various animal studies show that estrogen deficiency in ovariectomized rats influences the synthesis, release, and metabolism of dopamine (DA) and can deactivate dopamine receptor expression and function, which is reciprocated after estrogen treatment [19]. Secondly, estrogen may also exert neuroprotective effects on DA neurons by regulating expression of neurotrophic factors. Co-expression of ERs and neurotrophin receptors in the same brain regions and existence of estrogen response elements in the genes for nerve growth factor (NGF), BDNF and neurotrophin-3 suggest that estrogen can regulate neuronal survival [20]. As far as clinical data is concerned, preliminary studies suggest that estrogen may have beneficial effects on cognition in postmenopausal PD patients and may delay or prevent onset of dementia [21].

Various animal models of PD have been used to study the role of estrogens, SERMs, and ER subtype selective agonists in the development of PD [22]. ER- $\alpha$ knockout mice were more susceptible to 1-methyl-4-phenyl-1, 2, 3, 6-tetrahydropyridineinduced damage of dopamine neurons than were wild-type or 
ER- $\beta$ knockout mice. In wild-type mice, only the ER- $\alpha$ selective agonist (PPT) was reported to induce complete protection against MPTP-mediated loss of striatal dopamine neurons and dopamine transporter, whereas the ER- $\beta$ selective agonist DPN unsuccessful to do so $[1,22,23]$. These studies designate that estradiol mediated protection of PD is through ER- $\alpha$.

\section{Anxiety and Depression}

Women are more prone to get depression as compared to men and such risk is particularly associated with reproductive cycle events [24]. Various studies have verified that the transition to menopause is connected with increasing risk for new onset and persistent depression [25]. Although the mechanisms by which changes in ovarian hormones secretion lead to development of depression are not clear, however estrogen withdrawal theory suggests that reduction in gonadal hormone during transition of menopause exacerbates depressive mood and anxiety. ERs are situated in brain areas regulating the mood and behavior through serotonergic and noradrenergic neurotransmission. Estrogen insufficiency selectively reduces serotonin receptor density in hypothalamus and the preoptic area of CNS in ovariectomized rats which can be reversed by treatment with estrogen [26]. Furthermore, estrogen also enhances the levels of neutrophic factor such as brain derived neurotrophic factor (BDNF). Estrogen and ER agonists are reported to modulate the monoamine neurotransmitter systems by controlling monoamine synthesis and secretion [27]. DPN increased the tryptophan hydroxylase 2 expression of dorsal raphe of rats, however, WAY-200070 (selective ER- $\beta$ agonist) increased concentrations of serotonin and dopamine extracellularly [28].

Estrogen alterations during menopause cause anxiety in rodents, which can be modulated by estrogen administration. Female ER- $\beta$ knockout mice shows poorer serotonin levels and decreased dopamine content in several brain regions of anxiety as compared to wild-type mice. ER- $\beta$ deletion results decreased stimulation of synaptic plasticity by estrogen and enhancement of 5- hydroxytryptamine $1 \mathrm{~A}$ receptor expression in the amygdala. Moreover, estradiol did not show any antidepressant effect in ER- $\beta$ deficient ovariectomized mice comparative to wild-type mice. Selective ER- $\beta$ agonists produced anxiolytic and antidepressant effects in wildtype mouse models of anxiety and depression, however selective ER- $\alpha$ agonist did not show any effect. Same study also reported that, DPN decreased anxiety in both sexes, however PPT elicited anxiogenic behavior in rats [29].

\section{Stroke}

Stroke is the abrupt loss of brain function ascribed to ischemia which indicates a disturbance in the blood supply to the brain. Risk of stroke is lesser in premenopausal women as compared to men of the same age, but the occurrence of cerebrovascular events hastily results rise in postmenopausal women
[30]. Reason behind this seems to be pasting of the protective effects of estrogen. Various mechanistic evidences of protective effect of estradiol in ischaemia include reduction of inflammation of brain [31] and dysfunction of blood-brain barrier [32]; raising blood flow of the cerebrum [33], the ability of neurons to transmit signals and cognitive function; downgrading of excitotoxic ischaemic damage, oxidative stress and activation of various growth factors and signaling pathways, to preserve neuronal survival after injury or even to promote neurogenesis in the adult brain [34]. Studies involving mice with deleted ER- $\alpha$ and $\beta$ indicate that ER- $\alpha$ mediates estrogen protection of cortical neurons in animal model of focal ischemia [35]. However, ER- $\beta$ is implicated in the neuroprotective actions of estradiol in mice subjected to global ischemia and agonists selective for both ER $\alpha$ and $\beta$ can partially protect gerbil CA1 neurons from global ischemia-induced cell death [36].

\section{Schizophrenia}

Severity of symptoms of schizophrenia is greater in males as compared to premenopausal females [37-39]. Women have been shown to differ in symptom severity depending on the phase of the menstrual cycle [40]. Higher rates of relapse in women with schizophrenia are also observed during the postpartum period (low estrogens), whereas relapse is low during pregnancy (high estrogens) [41]. During menopause, women are at risk of developing a new schizophrenic illness [42]. Additionally, premenopausal women appear to have a superior response to typical antipsychotics compared to men and postmenopausal women. Estrogen plays a protective role in women with schizophrenia [43]. Estrogen treatment may reduce negative symptoms in schizophrenic women $[44,45]$. Estradiol may exert neuroprotection by several mechanisms that may even vary among different brain regions [46].

\section{Traumatic Brain Injury}

Traumatic brain injury (TBI), is an injury in the brain, causes serious disability and even death. Various studies have reported a significant gender difference in the occurrence and pathophysiology of TBI. Epidemiological evidences have shown that clinical prognosis after TBI is better in female than in male patients [47]. Estradiol has been found to be beneficial in different models of brain injury in animal models [47]. Estrogen provides powerful protection against formation of brain edema and prevents damage to the blood brain barrier, especially by reducing inflammatory responses such as suppression of the production of several proinflammatory mediators including protein expression and the levels of IL- $1 \beta$, IL- 6 , and TNF- $\alpha$. Estrogen reduces damage to the blood brain barrier by inhibiting the expression of MMP-9 and cyclooxygenase and increases cerebral blood flow by maintaining brain perfusion, reducing oxidative stress, and inhibiting the activation of microglia. The useful effects of steroids are not only limited to the nerve cells but also expand to the endothelial cells. Protective effects of 
estrogen on endothelial cells may enable them to protect the BBB against TBI [47]. Studies have shown that neuroprotective effect of estradiol might be mediated by both ER- $\alpha$ and $\beta$ on blood brain barrier permeability, anti-inflammatory activity, the production of interleukin, and regulation of neutrophil recruitment in to the brain [48].

\section{Conclusion}

Accumulating literature shows that female sex hormone $17 \beta$-estradiol is not only a reproductive hormone that is important only in women but it is also of immense importance for development and health in men. Although there is strong evidence from both human and animal studies that estrogen is protective in various brain diseases however, its adverse effect in classic target tissues such as uterus (17 $\beta$-estradiol behaves as a full agonist on both estrogen receptor (ER) isoforms) is a matter of debate. ER subtype selective ligands are valuable tools for deciphering the specific roles of ER ( $\alpha$ and $\beta$ ) in physiology and diseases. These compounds have a strong potential for development as therapeutics as these initiate estrogen signaling in brain but lack the mitogenic effects in other tissues such as ovaries and breast. Moreover, the existing and newer ERsubtype selective agonists will continue to be very valuable tool for deciphering the specific roles of ER- $\alpha$ and $\beta$ in health and diseases.

\section{References}

1. Brann DW, Dhandapani K., Wakade C, Mahesh VB, Khan MM (2007) Neurotrophic and neuroprotective actions of estrogen: basic mechanisms and clinical implications. Steroids 72(5): 381-405.

2. Gronemeyer H (1991) Transcription activation by estrogen and progesterone receptors. Annu Rev Genet 25: 89-123.

3. Kumar R, Thompson EB (1999) The structure of the nuclear hormone receptors. Steroids 64(5): 310-319.

4. Vrtačnik P, Ostanek B, Mencej-Bedrač S, Marc J (2014) The many faces of estrogen signaling. Biochem Med (Zagreb) 24(3): 329-342.

5. Brinton RD, Tran J, Proffitt P, Montoya M (1997) 17 beta-Estradiol enhances the outgrowth and survival of neocortical neurons in culture. Neurochem Res 22(11): 1339-1351.

6. Foy MR (2011) Ovarian hormones, aging and stress on hippocampal synaptic plasticity. Neurobiol Learn Mem 95(2): 134-144.

7. Rendeiro C, Spencer JP, Vauzour D, Butler LT, Ellis JA, et al. (2009) The impact of flavonoids on spatial memory in rodents: from behaviour to underlying hippocampal mechanisms. Genes Nutr 4(4): 251-270.

8. Shughrue PJ, Scrimo PJ, Merchenthaler I (2000) Estrogen binding and estrogen receptor characterization (ERalpha and ERbeta) in the cholinergic neurons of the rat basal forebrain. Neuroscience 96(1): 4149 .

9. Luine VN (1985) Estradiol increases choline acetyltransferase activity in specific basal forebrain nuclei and projection areas of female rats. Exp Neurol 89(2): 484-490.

10. Yamada M, Huang Z, Dalkara T, Endres M, Laufs U, et al. (2000) Endothelial nitric oxide synthase-dependent cerebral blood flow augmentation by L-arginine after chronic statin treatment. J Cereb Blood Flow Metab 20(4): 709-717.
11. Bishop J, Simpkins JW (1995) Estradiol enhances brain glucose uptake in ovariectomized rats. Brain Res Bull 36(3): 315-320.

12. Benvenuti S, Luciani P, Vannelli GB, Gelmini S, Franceschi E, Serio M, Peri A (2005) Estrogen and selective estrogen receptor modulators exert neuroprotective effects and stimulate the expression of selective Alzheimer's disease indicator-1, a recently discovered antiapoptotic gene, in human neuroblast long-term cell cultures. J Clin Endocrinol Metab 90(3): 1775-1782.

13. Spampinato SF, Molinaro G, Merlo S, Iacovelli L, Caraci F, et al. (2012) Estrogen receptors and type 1 metabotropic glutamate receptors are interdependent in protecting cortical neurons against beta-amyloid toxicity. Mol Pharmacol 81(1): 12-20.

14. Hestiantoro A, Swaab DF (2004) Changes in estrogen receptor-alpha and -beta in the infundibular nucleus of the human hypothalamus are related to the occurrence of Alzheimer's disease neuropathology. J Clin Endocrinol Metab 89: 1912-1925.

15. Kelly JF, Bienias JL, Shah A, Meeke KA, Schneider JA, Soriano E, Bennett DA (2008) Levels of estrogen receptors alpha and beta in frontal cortex of patients with Alzheimer's disease: relationship to Mini-Mental State Examination scores. Curr Alzheimer Res 5(1): 45-51.

16. Carroll JC, Pike CJ (2008) Selective estrogen receptor modulators differentially regulate Alzheimer-like changes in female 3xTg-AD mice. Endocrinology 149(5): 2607-2611.

17. Bagheri M, Joghataei MT, Mohseni S, Roghani M (2011) Genistein ameliorates learning and memory deficits in amyloid beta (1-40) rat model of Alzheimer's disease. Neurobiol Learn Mem 95(3): 270-276.

18. Gillies GE, Pienaar IS, Vohra S, Qamhawi Z (2014) Sex differences in Parkinson's disease. Front Neuroendocrinol 35(3): 370-384.

19. Shulman LM (2002) Is there a connection between estrogen and Parkinson's disease? Parkinsonism Relat Disord 8(25): 289-295.

20. Scharfman HE, MacLusky NJ (2006) Estrogen and brain-derived neurotrophic factor (BDNF) in hippocampus: complexity of steroid hormone-growth factor interactions in the adult CNS. Front Neuroendocrinol 27(4): 415-435.

21. Saunders-Pullman R, Gordon-Elliott J, Parides M, Fahn S, Saunders HR., et al. (1999) The effect of estrogen replacement on early Parkinson's disease. Neurology 52(7): 1417-1421.

22. Gillies GE, McArthur S (2010) Estrogen actions in the brain and the basis for differential action in men and women: a case for sex-specific medicines. Pharmacol Rev 62(2): 155-198.

23. Vegeto E, Benedusi V, Maggi A (2008) Estrogen anti-inflammatory activity in brain: a therapeutic opportunity for menopause and neurodegenerative diseases. Front Neuroendocrinol 29(4): 507-519.

24. Soares CN, Frey BN (2010) Challenges and opportunities to manage depression during the menopausal transition and beyond. Psychiatr Clin North Am 33(2): 295-308.

25. Frey BN, Lord C, Soares CN (2008) Depression during menopausal transition: a review of treatment strategies and pathophysiological correlates. Menopause Int 14(3): 123-128.

26. Aggarwal M, Puri V, Puri S (2012) Effects of estrogen on the serotonergic system and calcitonin gene-related peptide in trigeminal ganglia of rats. Ann Neurosci 19(4): 151-157.

27. Nilsson S, Gustafsson JA (2011) Estrogen receptors: therapies targeted to receptor subtypes. Clin Pharmacol Ther 89(1): 44-55.

28. Bodo C, Rissman EF (2006) New roles for estrogen receptor beta in behavior and neuroendocrinology. Front Neuroendocrinol 27(2): 217232. 
29. Osterlund MK (2010) Underlying mechanisms mediating the antidepressant effects of estrogens. Biochim Biophys Acta 1800(10): 1136-1144.

30. Oliveira PJ, Carvalho RA, Portincasa P, Bonfrate L, Sardao VA (2012) Fatty Acid Oxidation and Cardiovascular Risk during Menopause: A Mitochondrial Connection? J Lipids 2012: 365798.

31. Suzuki S, Brown CM, Wise PM (2009) Neuroprotective effects of estrogens following ischemic stroke. Front Neuroendocrinol 30(2): 201-211.

32. Liu R, Wen Y, Perez E, Wang X, Day AL, et al. (2005) 17beta-Estradiol attenuates blood-brain barrier disruption induced by cerebral ischemia-reperfusion injury in female rats. Brain Res 1060(1-2): 5561.

33. Pelligrino DA, Santizo R, Baughman VL, Wang Q (1998) Cerebral vasodilating capacity during forebrain ischemia: effects of chronic estrogen depletion and repletion and the role of neuronal nitric oxide synthase. Neuroreport 9(14): 3285-3291.

34. Sherwin BB (2007) The clinical relevance of the relationship between estrogen and cognition in women. J Steroid Biochem Mol Biol 106(1-5): 151-156.

35. Dubal DB, Zhu H, Yu J, Rau SW, Shughrue PJ, et al. (2001) Estrogen receptor alpha, not beta, is a critical link in estradiol-mediated protection against brain injury. Proc Natl Acad Sci U S A 98(4): 19521957.

36. Miller NR., Jover T, Cohen HW, Zukin RS, Etgen AM (2005) Estrogen can act via estrogen receptor alpha and beta to protect hippocampal neurons against global ischemia-induced cell death. Endocrinology 146(7): 3070-3079.

37. Gupta R, Assalman I, Bottlender R (2012) Menopause and schizophrenia. Menopause Int 18(1): 10-14.

38. Larsen TK, McGlashan TH, Johannessen JO, Vibe-Hansen L (1996) Firstepisode schizophrenia: II. Premorbid patterns by gender. Schizophr Bull 22(2): 257-269.
39. Markham JA (2012) Sex steroids and schizophrenia. Rev Endocr Metab Disord 13(3): 187-207.

40. Madularu D, Shams WM, Brake WG (2014) Estrogen potentiates the behavioral and nucleus accumbens dopamine response to continuous haloperidol treatment in female rats. Eur J Neurosci 39(2): 257-265.

41. Cyr M, Calon F, Morissette M, Di Paolo T (2002) Estrogenic modulation of brain activity: implications for schizophrenia and Parkinson's disease. J Psychiatry Neurosci 27(1): 12-27.

42. Pena Salas GF, Gaviria SL (2013) Schizophrenia after forty and its relation with estrogens. Vertex 24(111): 325-332.

43. Hafner $\mathrm{H}$, an der Heiden W, Behrens S, Gattaz WF, Hambrecht M, et al. (1998) Causes and consequences of the gender difference in age at onset of schizophrenia. Schizophr Bull 24(1): 99-113.

44. Kulkarni J, Riedel A, de Castella AR, Fitzgerald PB, Rolfe TJ, et al. (2001) Estrogen - a potential treatment for schizophrenia. Schizophr Res 48(1): 137-144.

45. Lindamer LA, Buse DC, Lohr JB, Jeste DV (2001) Hormone replacement therapy in postmenopausal women with schizophrenia: positive effect on negative symptoms? Biol Psychiatry 49(1): 47-51.

46. Azcoitia I, Doncarlos LL, Garcia-Segura LM (2002) Estrogen and brain vulnerability. Neurotox Res 4(3): 235-245.

47. Asl SZ, Khaksari M, Khachki AS, Shahrokhi N, Nourizade S (2013) Contribution of estrogen receptors alpha and beta in the brain response to traumatic brain injury: laboratory investigation. J Neurosurg 119(2): 353-361.

48. Mohammadi F, Pourahmadi M, Mosalanejad M, Jamali H, Ghobadifar MA, et al. (2013) Association of Estrogen Receptor alpha Genes PvuII and Xbal Polymorphisms with Type 2 Diabetes Mellitus in the Inpatient Population of a Hospital in Southern Iran. Diabetes Metab J 37(4): 270277.

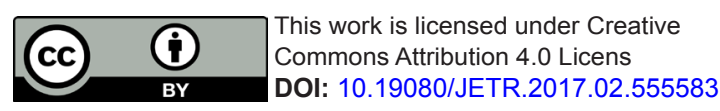

\begin{tabular}{l} 
Your next submission with Juniper Publishers \\
will reach you the below assets \\
- Quality Editorial service \\
- Swift Peer Review \\
- Reprints availability \\
- E-prints Service \\
- Manuscript Podcast for convenient understanding \\
- Global attainment for your research \\
- Manuscript accessibility in different formats \\
( Pdf, E-pub, Full Text, Audio) \\
- Unceasing customer service \\
Track the below URL for one-step submission \\
https://juniperpublishers.com/online-submission.php \\
\hline
\end{tabular}

